\title{
Changing Caribbean geographies \\ Connections in flora, fauna and patterns of settlement from Indian inheritances
}

\author{
Brinsley Samaroo \\ Brinsley Samaroo is professor of history (emeritus), University of \\ the West Indies
}

\section{ABSTRACT}

There can be no doubt that Indian immigration to the plantation colonies changed the geography of those colonies. However, most analyses have dealt with the sugar industry in the colonies after the abolition of slavery. This paper will argue that, apart from the sugar industry, Indian labour and ingenuity made other significant contributions to plantation economies. The girmityas (agreement signers) were well aware that they were going to agricultural occupations so they took with them an amazing array of dried fruits, seeds and cuttings, which survived the long crossing, adding to the flora of the plantations. Armed with this foreknowledge, the jahajis packed these items into their jahaji bundles alongside the Tulsi Ramayan and the Holy Qu'ran. Animals too formed part of this international trade. Sheep, goats and poultry which were not eaten on the outward voyage were sent to the estates, where they multiplied. When dangerous snakes threatened plantation security, cages of mongoose were dispatched to the Caribbean where they bravely tackled venomous creatures. At the urging of Indian labourers with long experience in the sugar industry, the plantations' owners imported Brahma bulls and Zebu cattle, which revolutionised transport on the estates and provided leather, manure and meat to the wider population.

There is also the amazing story of the importation of hundreds of water buffaloes (bhaisa) from the Indo-Gangetic plains. Some nine breeds were imported and in the twentieth century Caribbean bio-geneticists were able to blend the best qualities of those Indian animals and created a new hybrid, the buffalypso, which combined 
the scientific name with Trinidad's fame as the land of the calypso. The buffalypso became a prized animal for haulage, meat, milk and leather and an item of export to Venezuela, Colombia, Miami and the wider Caribbean. Indian cultivars were continuously exported to the botanic gardens in the Caribbean and Indian forestry experts were sent to the region to advise on forest rehabilitation in the wake of large-scale deforestation, which sugar cultivation required. In these and other ways the physical character of the Caribbean underwent permanent change, which manifests itself today.

\section{KEYWORDS}

Caribbean geographies, Jahaji bundle, Girmityas, buffalypso, Ramayana in indenture, Qu'ran in indenture, seeds in indenture, Indian animals in the Caribbean

In 1886 the Scottish American traveller William Paton visited Trinidad as part of a larger Caribbean tour. As he walked through 'the cooly quarter of San Fernando' he marvelled at the manner in which the Western, Caribbean town was being Orientalised by the East Indian presence. His description of the San Fernando market would hardly have been different from sections of the Bourda market in Guyana's main city or the farmers' market in Paramaribo, Suriname. Here in Trinidad the Bihari market had been recreated, complete with the sacred banyan tree, transported as part of the floral transfers from India to the Caribbean:

In the midst of this cooly district there is an open space, an acre or two in extent, densely shaded by a very ancient and far-spreading banyan tree, under the branches of which the cooly people hold their market. It would be impossible to imagine a scene more unlike any that I have ever beheld in all my travels in America or Europe.The people, their wares, their manner of trading, their baskets, trays, tables, their manner, voices, gestures, all were strange and outlandish, for the Hindus lose but little of their national characteristics in the NewWorld.As I passed through the crowd the sellers saluted respectfully, bowing as they said, 'Salaam, sahib'; then eagerly, but without clamour or violent gestures, besought me to 
purchase queer-looking eatables, utensils, ornaments, fabrics - in a word, all sort of merchandise. There were vendors of curry and curry-powder, purveyors of all kinds of food preserved in curry, curry to be taken away or to be eaten then and there - paper-packages, boxes, bottles of it, jars, pots, cups, bags, coconut-shells, full of curry - and everything, living or inanimate, in the market-place, was as distinctively East Indian as the curry itself, save and excepting a few Africans, Chinese, and Europeans, and their chattels and belongings. (Patton 1887:203)

During the long period of Indian indentureship in the British, French and Dutch Caribbean, lasting from 1838 to 1920, approximately half a million agreement signers (girmityas) travelled over a distance of some 15,000 kilometres as they crossed the Pacific, Antarctic and Atlantic Oceans. This journey, which lasted about three months, included very rough passage through the 'Pagal Samundar' or Mad Sea, which tumbled the ship as it passed through the treacherous waters off Cape of Good Hope. Although the Cape was not a scheduled stop on the way to the Caribbean, many a battered ship was forced to make a stop there for repairs before it could proceed to the mid-Atlantic island of St Helena for refuelling and for fresh water and vegetables. As is generally known, those girmityas came to fill an artificially created labour shortage in the Caribbean following the emancipation of slaves in 1838. There are many dimensions to this trade in human beings from the poverty-stricken, de-industrialised regions of North India and, to a lesser extent, from Madras in the South. For one thing, European traders now created a new triangular trade which replaced the old triangular routes from Africa to the Caribbean, whereby millions of people and a wide variety of flora were brought to the Caribbean. After the shifting of the trade in bodies which established Africa in the Caribbean, the new nexus introduced India to the Caribbean and similarly altered the ethnic composition, cultural expressions and physical character of an area which Columbus had erroneously called West India in his futile search for a route to the East, hence the subsequent designation: West Indies. Columbus's error was now being rectified many centuries later. Indians were now peopling the region. 
From 1838 when a 'new system of slavery' was introduced with the arrival of two shiploads of Indians to British Guiana, European governments and private investors continued to accumulate their accustomed fortunes as the trade now replaced Africa with India in triangular fashion. Diagram 1 shows the continuing enormity of this redesigned commerce.

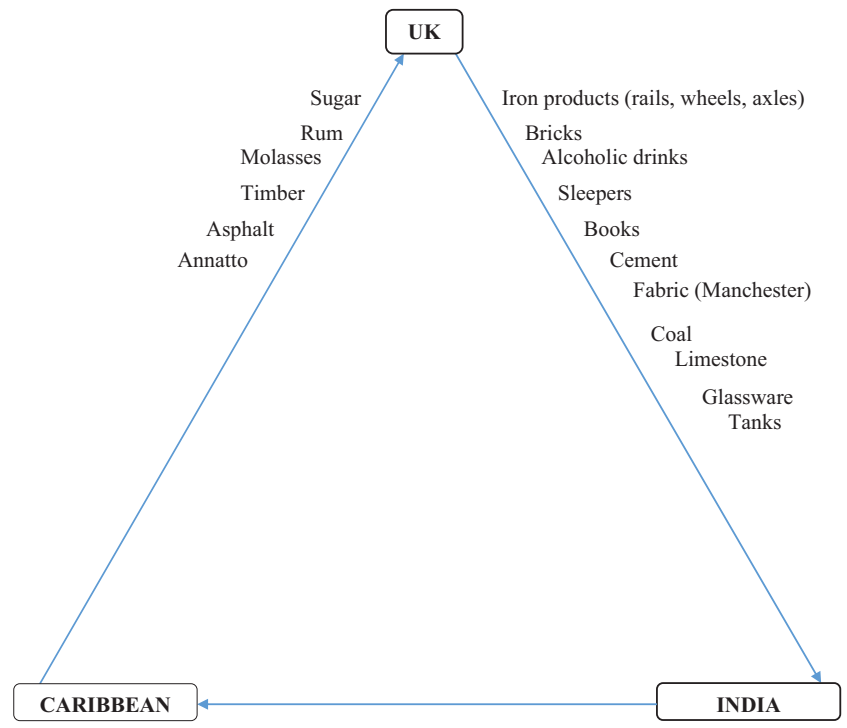

Indentured labourers, rice, tea, hides, linseed, dhal, gunny bags, leather, spices, oriental plants and animals, mustard oil, castor oil, silk, goods, musical instruments

DIAGRAM I Trade and commerce between the Atlantic and Pacific Oceans I838-1917

The available evidence indicates that most of the bonded labourers knew they were going to the colonies to do agricultural work. In fact most of the immigrants were recruited from the agricultural belt stretching from Bengal in the East to Rajasthan in the West, the major flood plains of mighty rivers streaming down from the 
Himalayan heights. The recruiters (arkatias) used destination names which were alluring, such as Chini-Dad (land of sugar) or Mirch Desh (land of peppers, for Mauritius). To these very religious people, Suriname was portrayed as Sri Ram. Returning immigrants from the mid-nineteenth century also described the work to their compatriots who left in their thousands as the economic situation worsened in their villages. With this foreknowledge the Indians devised clever ways of transferring the flora and the fauna of their native environment. Unlike the Africans who were not allowed to board the slave ship with their belongings, the Indians were granted a small leeway in that they could pack their prized possessions into a large, triangular piece of fabric called the jahaji bandal (ships' belongings) fastened to a lathi (rod) which was held over the shoulder. Most of the Hindus stored their Tulsi Ramayana and the Muslims, the Holy Qu'ran. Equally important was an amazing array of seeds and cuttings, fruits and other herbs, which certainly changed the geography of the Caribbean and other diasporic colonies.

\section{THE ANCESTRAL URGINGS}

There could have been no better place for the derivation of flora and fauna for plantation colonies than Maha Bharat, that is, Greater India. The civilisation was formed as a series of agricultural settlements, initially along the Saraswati River in the Indus valley. The Saraswati dried up around $1900 \mathrm{BCE}$ and the population moved eastwards along the foothills of the Himalayas and within the confluence of the Ganga and Yamuna Rivers. This area, centuries later, became the major recruiting area for those who went to Fiji, Mauritius, Natal and the Caribbean. The narrative of the early development of this agricultural society is contained in what is perhaps the earliest compilation of literature, namely the Vedas, the writing of which started around $3000 \mathrm{BCE}$ and concluded around 1600 BCE. The major Vedas, namely the Rig Veda, Yajur Veda and Athara Veda, speak of the development of plant 
and animal sciences and methods of cultivation. David Frawley, using these sources, tells of the soma plant, the possible ancestor of the sugar cane, growing as a reed in marshy or aquatic areas (2001: 154). Soma was one of the mighty rivers streaming down from the Himalayan heights. These early agricultural skills became part of the bio-genetic memory which enabled the girmityas to easily adapt to sugar or other cultivation wherever they went. North India was 'a fertile region that allowed for an easy development of agriculture' (Frawley 2001: 318).

To the citizens of Vedic India and their descendants over the millennia, agricultural practice was not only a means of obtaining physical sustenance. It was a sacred duty and both rajas and rishis regarded the promotion of agriculture as their dharmic duty. Flora and fauna became objects of divinity. The Tulsi Ramayana, the major transported text to the Indian plantation diaspora, enjoins the devotee to offer leaves, flowers, fruit and water as acceptable offerings. To the Indian the earth is sacred (Dharti Mata), meaning Mother Earth, and the cow is Gai Mata (Mother Cow). Flowers have always played a central role in cultural practice, symbolising beauty, purity and the divine presence. Mother Lakshmi is portrayed as emerging from the dark primeval ocean on the cusp of a lotus flower bringing prosperity to her devotees. Similarly, Sarswati, the goddess of learning, emerges from a lotus radiating knowledge in all directions. The seeds of flowers formed a major item of the jahaji bundle.

Around 14 per cent of the girmityas were Muslims who took to their diasporic destinations the Qu'ranic injunctions about the importance of the cultivation of crops. The Qu'ran speaks nostalgically about the garden with dates and vines, with streams flowing in the midst of all kinds of fruits (Sura II Ayat 266). All of these are gifts from the divine and have signs for those who believe (VI 99). The Mughals who ruled India from 1526 to 1858 also left their footprint through the promotion of plant sciences, medicine and floriculture. The Mughal Gardens in Kashmir, still in bloom, are a 
wondrous sight to behold. Similarly, the Taj Mahal, with its abundant floral designs, was constructed in Agra, a major recruiting area. The ancestors of those who were later taken abroad must have been among the thousands who built the Taj. Those skills were later taken to the colonies.

The results of this philosophical socialisation into agricultural practice became evident in the diasporic colonies. Jo Beall tells of the widespread use of Indians in Natal in the sugar industry as well as on farms. The tea industry was dependent on female labour and it collapsed after the end of indentureship (Beall 1990: 96). Goolam Vahed, writing later, cites the evidence of one of the largest planters in Natal, Sir Liege Hulett, that the condition of the colony before the importation of Indian labour was one of gloom but now in 1908, the coast had been turned into one of the most prosperous parts of South Africa (Vahed 1995: 42). Vahed also indicated that as late as 1949 Indian market gardeners supplied 75 per cent of vegetables for the general public in Durban. Here, as in other parts of the diaspora, the work was shared among the entire family, each member performing specific tasks (1995: 75).

The list of items of flora which were fitted into this jahaji bandal is long and impressive. Among these were mango (aam), guavas (amrudh), pomegranate (anar), string-bean (bodi), Indian drumsticks (saijan/moringa), pumpkins (khora, khadu), marijuana, datura, rice (chawal), sapodilla (chicu), betel-nut (supari), turmeric (haldi), bitter gourd (caraillee), ginger (adhrak), curry-plant (karapillay), cinnamon (dalchini), mustard (sarson), black pepper (kali mirch), onion (pyaj), cumin (geera), fennel (sauf), fenugreek (maithi), long gourd (lowki), cloves (laung) and the seeds of the ashoka, bael, neem and lotus (kumud). In the jahaji bandal they brought a whole range of spinach (bhaji) seeds as well as the full panoply of Indian lentils (dhal). Some of these seeds, such as guava and citrus, had been brought to the region before the arrival of the Indians but India now supplied new varieties which improved the native stock. In the jahaji bandal there were seeds of loofa (jinghi), tamarind (imli) and cucumber (khera). 
Whilst there was this informal transfer of flora via the jahaji bandal, transfer also occurred through more official means. One major institution of agency was the Royal Botanical Gardens at Kew, just outside London, which over centuries has been a major research station, linking the many parts of the British Empire. In 1765 the colonial administration established the St Vincent Botanic Gardens to facilitate the movement of plants across the Caribbean. Similar botanic gardens were subsequently set up in the other Caribbean colonies to facilitate the transfer of flora for food, medicine or items of trade (Pemberton 2000: 330-1). In this way the mango (magnifera indica) came to the Caribbean before the Indians brought their additional varieties. In 1782 a shipment of Indian mangoes from Mauritius, destined for the French West Indies, was captured by the British and the plants were sent to Jamaica from whence the fruit made its way to the other Caribbean colonies. Since that time the mango has been abundantly cultivated throughout the region. In 1900 the Trinidad Botanic Gardens imported new varieties from Bombay, Bengal and Madras. The fruit has become naturalised and has been the constant theme of song and story. Its wood makes the best drums, its leaves are used daily in Hindu religious ceremonies and its branches are prized at cremation centres. As Caribbean Indians have moved northwards to the USA and Canada the leaves and twigs are imported from the Caribbean for religious ceremonies and mango curry forms an essential part of the meal.

In other trading arrangements, Indian plants were introduced. For example, the jackfruit (A. integrifolia), known as 'cowa' in the Caribbean, was imported, as was black pepper (pipernigrum), brought from Travancore and Malabar in South India. In 1806 two nutmeg plants were brought from India to Trinidad and were sent to St Vincent where they were successfully cultivated. In 1820 mature plants were sent back to Trinidad where they were soon cultivated commercially in the valleys of the Northern Range. At this time also, Grenada received its nutmeg seeds from which a major 
industry, still in profitable existence, was started. Similarly through inter-botanical garden transfers, the hibiscus (hibiscus tiliaceus) was brought to the Caribbean, becoming as prolific as the mango, a constant sight in all countries, used for daily worship, as a tooth brush, as fodder for animals and to create pretty hedges and flower gardens. In addition, cocoa producers in the Caribbean found, in the Poovan banana plants, imported from Mysore, an ideal shade for their young plants as well as a delicious fruit which sold well in the marketplace.

Following the Anglo-American war of 1812 to 1815 hundreds of African Americans, now refugees, were settled in Trinidad, mainly in the Moruga area. These migrants brought hill rice from the Chesapeake Bay region to Trinidad. Today there are still patches of hill rice in the Company villages. The Indians supplemented this inflow of hill rice by bringing a wide variety of swamp rice whose later production became major industries in Guyana and Suriname as well as in the Caroni, Nariva and Oropuche lagoons of Trinidad. The indentured Indians brought varieties such as balam, mooghyri and basmati and these became widely acceptable. Trinidad's department of agriculture made regular importations of other rice cultivars such as Kaijury, Kartic Sail, Lal and Kalai Aman. ${ }^{1}$ From Trinidad these varieties were exported to the South American mainland.

\section{RESTORING THE ENVIRONMENT}

Despite the introduction of these many varieties of flora, the major purpose for the creation of Caribbean society was the plantation system based on sugar. However, as the sugar industry constantly expanded, there was considerable environmental degradation. Huge stands of forest were denuded to make way for new plantations and trees were cut to provide fuel for the mills. Soon the forest hamlets and groves of ancient trees were replaced by drab canescapes, extending for many miles. Flooding now became a problem as the forest cover was removed. As migrants 
from a civilisation which worshipped the earth as Dharti Mata and clearly understood the need for environmental preservation, the Indians contributed significantly to the restoration of the Caribbean environment. As they settled in the villages around the canefields they created prosperous habitations in the coastal regions of British Guiana and Suriname, in the Westmoreland canefields of Jamaica and on the Caroni and Naparima plains in Trinidad. In these settlements they planted the flora brought from India as food, medicine, religious aids and for the local market. They drained swamps in the Caribbean and created villages where none existed before, often giving ancestral names to these new places: Fyzabad, Barrackpore, Calcutta Settlement, Madras, Malabar, Coromandel, Chander Nagar and Coolie Wood. One of the earlier settlements on the outskirts of Port of Spain still carries the names of streets which were formerly lagoons, made habitable by Indian enterprise. Many streets carry ancestral names such as Bombay, Nipal, Mooneram, Calcutta, Agra, Meerut and Cawnpore.

In these recreated settlements the Indians recalled and reinvented artefacts which had sustained them in their birthplace: jata and dhenki (for threshing grain), musar and okhri (mortar and pestle), haswa (sickle) and a host of other items of daily use. As they relaxed after work they introduced new musical sounds as they sang and danced to the accompaniment of musical instruments which had provided entertainment on the ships: majeera (small brass cymbals), dhol (bass drums), dholak (double-mouthed hand drum), tambourines and harmoniums among others. Now they added new festivities to the cultural landscape: Divali, Hosea, Ram Lila, Kartik Snaan and many rites of passage such as weddings, birth celebration (chhati and barahi) Ramayan Yagnas and many types of kathas (prayer ceremonies). The ceremonial jhandi (flag) transferred from Bihar and Uttar Pradesh has remained as a permanent fixture in these Caribbean colonies. In these ways new physical and cultural spaces have been created and are on the increase, adding to Caribbean diversity. 
Whilst the Indians moved quickly to restore the physical spaces which suffered degradation, the colonial authorities showed a later concern for restoration. From 1887 the Indian Forest Service was summoned to the Caribbean to advise on reforestation projects in Trinidad and later in Tobago (Pemberton 2000: 330). In this process one of the Indian species introduced was hardwood teak, which since that time has become a profitable industry. In fact over the last few decades the export of teak cuttings from the Caribbean to India for the creation of small artefacts has become a cottage industry.

\section{ANIMALS FROM INDIA}

The introduction of animals for the promotion of the sugar industry in the Caribbean is perhaps as important as the flora just described. Caribbean plantations were very concerned about snake and rat infestation of their fields. For this reason, the Indian mongoose was brought to Jamaica in 1860, Barbados in 1870 and St Lucia in 1885. From these islands the animal was exported to sugar estates as far north as Cuba and Puerto Rico (Mahabir 2004: 179). Eventually these rodents became pests, particularly to poultry farmers who have had to take all kinds of precautionary measures to protect their flocks. Another useful animal brought to the Caribbean was the goat. Hundreds of goats were introduced as leftovers from the indenture ships. Goats and sheep were taken on board to supplement the ship-board meals for the lascars (Indian sailor) and for non-vegetarian immigrants. Some of these animals reached the Caribbean and were distributed among the estates, where their hardiness ensured their reproduction in the new place. As British breeders realised the potential of these ruminants for meat, milk and hide production, they were crossed with other varieties and sent to the Caribbean.

Another animal brought on the indenture ships was the Indian zebu cattle whose huge hump stores water for use when normal 
sources are unavailable. These strong animals were used as replacements for estate mules which often foundered in the heavy clay soils of the plantations. During the second half of the nineteenth century they were extensively used in the British and French Caribbean not only for haulage but also for meat, leather and milk. Initially these animals were transported on the indenture ships and within a few years they proved to be very profitable on the plantations. However in 1893 their exportation from India was prohibited because the ship-owners complained that these animals were taking up too much space on their ships, thus cutting into their profits. They also complained that the animals made the decks 'dirty and offensive'. ${ }^{2}$ Despite these objections some zebu animals were smuggled into Trinidad as the demand for zebus grew louder. By the end of the nineteenth century this matter was raised at the highest levels of colonial administration. In September 1897 Trinidad's governor repeated his request, first made in June 1897 , for the resumption of the trade in Indian cattle. The government farm wanted Hissar zebu animals as well as the smaller Cingalese cattle known in India as 'the poor man's beast'. These animals, the governor argued, 'would fatten easily on our grasses which are superior to those of Ceylon'. Trinidad wanted three cows and a bull and was prepared to pay $£ 10$ per head. ${ }^{3}$

The governor's request was supported by Meaden, the manager of the government farm who lamented that the zebu bull on the farm brought in 1894 was now showing signs of weakness. He now urged that:

No reasonable expense should be spared in getting a really good animal, not exceeding three years old.A good coolie to be sent in charge of the bull, probably a return coolie could be found. The captain of the vessel to be promised a gratuity of $£ 5$ in the event of the animal arriving safe and sound. We have obtained a most favourable and profitable reputation for this class of cattle throughout the West Indies and it is most desirable that this position should be obtained. 
This Caribbean demand for Indian cattle was encouraged by Warner, the Trinidad Immigration Agent, from his Calcutta base. He urged the Secretary of the State to rescind the 1893 ban on the transportation of Indian cattle to the Caribbean. These animals, he argued, could be placed on emigrant ships "in which there are several hundred coolies who worship cattle and would be likely to take the greatest care of the animal'. In October 1897 the Crown Agents (who facilitated trade among colonies) were instructed by the Colonial Office to remove the ban on the 'largest and heaviest type of draught or beef animals'. ${ }^{4}$

This clearance resulted in the resumption of the trade in Indian cattle. In August 1902 the government farm requested the zebu heifers so that milk production could be enhanced. ${ }^{5}$ Six years later the trade was in full swing. Jamaica had started importing zebus in 1906. In November 1908 the Caroni Estate ordered two to three pure-bred zebus from Calcutta to improve the local stock which had weakened because of inter-breeding. William Kay, the Caroni manager, advised that, since steam ships had now replaced sailing ships, the journey from India had been reduced by two-thirds. In this way shipping costs could be reduced. ${ }^{6}$ Over time, however, poor husbandry on the estates led to a high incidence of tuberculosis, causing considerable loss among the herds. A search again led to India where the water buffalo (bos bubalis) had been in use since around 3000 BCE. In addition to being a good haulage animal, the 'bhaisa' was an excellent milk producer and at the beginning of the twentieth century, India was an exporter of over five million hides annually. The animals' thick skins kept mites away and they were rarely troubled by flies and screw worms which normally wrought havoc among cattle. ${ }^{7}$

From 1905 water buffaloes were imported by planters into Trinidad and by the time of the First World War they were being widely used on the estates. Such importation continued until 1949 by which time at least eight breeds had arrived in the Caribbean. Among these were the Murrah, Surti, Jaffarbadi, Mehsana, Nagpuri, 
Nelli, Ravi and Bhadawaria. Over the decades these breeds were intermixed as they became popular not only on the sugar plantations but equally in the rice fields. In Trinidad, as in Venezuela and Colombia, it was found that the "buffaloes thrived well in grass that was high in fibre and were well adapted to the hot humid tropical conditions in Trinidad and the Caribbean'. In addition they were much easier to break in than zebu cattle (Bennett et al. 2003). A study published by researchers at the University of the West Indies in 2017 reported that water buffalo meat is more tender than beef from Brahma cattle of the same age, gender and diet. The study also indicated that water buffalo milk is higher in fat than cow's milk and has been used locally to make cottage cheese (paneer), yoghurt (dahi), ghee and sweets (barfi). ${ }^{8}$ In Trinidad, which became the leading centre for the production of buffaloes, precautions were taken to ensure better husbandry. At Caroni Limited, the colony's major sugar producer, concrete floors were built replacing the old, earthen floors, the pens were provided with mangers and racks and a strict tuberculin regimen was introduced. New feeds were developed using coconut meal, urea and molasses. With these improvements tuberculosis was eliminated by 1958. By this time too the state employed a number of veterinarians who advised the farmers on best practice.

Among the new cadre of veterinarians there was one who made a significant difference. Stephen Bennett (1922-2013) was born in Trinidad and after his secondary education in this colony he studied in Canada and the United States, graduating as a veterinarian in 1948. In that year he returned to Trinidad and took up appointments with two plantations which had herds of buffaloes. Bennett immediately undertook a project of genetic selection and cross-breeding, seeking to produce a new animal:

The type of buffalo that we were aiming for is a reddish brown or copper coloured, white forehead, tight-coated with prominent eyes and the horns going backwards and curling upwards. It is our hope that we will develop a 
buffalo that is docile, will grow quickly, be heavy, compact, strong for working and adaptable as a meat-producing animal. (1964)

By 1967 Bennett's dream had come to pass. By that time the new animal, named the buffalypso (combining the animal with Trinidad's fame as the land of the calypso) was being exported to Venezuela and Colombia. Later shipments went to Argentina, Costa Rica, Miami, Brazil, Panama, Mexico and as far as Taiwan. By 2004 the milk was being used in the making of yoghurt, soft cheeses, ice cream, ghee, mozzarella cheese, queso blanco and queso de mano. The Indian bhaisa was perhaps the most important faunal gift to the Caribbean.

\section{RECREATING SIMLA}

The story of the life and research of a very prominent American scientist William Beebe (1877-1962) illustrates the importance of the Indian role in the reshaping of the Caribbean. Beebe stands out as one of the twentieth century's major ornithologists, a deep-sea diver, entomologist and recorder of the world's micro-habitats. ${ }^{9} \mathrm{He}$ travelled world-wide, gathering evidence for his many studies. In India he befriended Rudyard Kipling whose Indian writing he admired. He did further research in Sri Lanka, Indonesia, Venezuela and Guyana. In these endeavours he was strongly supported by the New York Zoological Society to which he was a major consultant. He first visited Trinidad in 1908 and liked the place so much that he returned in 1949 to spend the rest of his days there, departing this life at the ripe age of 92. In 1949 he purchased Verdant Vale, a large estate on a hill overlooking the town of Arima, a scene reminiscent of the hill stations of Northern India. Here he tried to recreate the tranquil Indian hill station called Simla where he had done some of his research. He called the highland retreat 'Simla' and recreated nature walks and animal havens on the ledges in the Indian mode. From that time Simla became a favourite spot for bird-watchers, 
trekkers and wildlife researchers. He even hired an East Indian, Ramdial, whose fore-parents had come from North India, as guide and general superintendant. After Beebe's death in 1962 the station was maintained by the New York Zoological Society which increased its holding to 265 acres. In 1974 the Society donated this ecological treasure to the Asa Wright Nature Centre which had developed a similar institution on the adjacent Spring Hill Estate. It was absorbed into the larger Asa Wright project which up to the present time continues the work pioneered by William Beebe, preserving a rare habitat, supported by environmentalists worldwide.

\section{RESHAPING CULTURAL GEOGRAPHIES}

In 1991 the Barbadian novelist George Lamming commented on the ways in which Indian labour had changed the cultural landscape of Caribbean nations. His observations relate specifically to Guyana and Trinidad but they are equally applicable to Suriname: 'There can be no history of Trinidad and Guyana that is not also a history of the humanization of these landscapes by Indian and other human forces of labour' (p. 21).

In his early morning trips to the Port of Spain market, Lamming was amazed to see the wide variety of fruits and vegetables being sold by Indian traders. He wondered how far they had travelled, when they had started their journeys and whether the country 'realized that it was these invisible hands that had fed it'. These Indian hands created the extensive rice fields in colonies like Guyana, Suriname and Trinidad, adding rice to the Caribbean diet which hitherto consisted mainly of imported wheat and potatoes and locally grown ground provisions and breadfruit. Caribbean cuisine was enhanced by the addition of recipes brought from the villages of Northern and Southern India which gave us rotis, curries and a wide variety of vegetable dishes (talkarie) and sweet-meats. There have also 
been culinary innovations, two of which will be mentioned here. The paratha roti now enjoyed throughout the diaspora was the ship-board creation of the cooks (bhandaries) on the immigrant ships. Faced with the onerous daily task of baking flatbreads (chappaties) for hundreds of immigrants the cooks embarked on a remarkable innovation. They persuaded the ship-owners to order large griddles (tawas) from the iron-mongers at Calcutta. Every morning they rolled a large dough (loi) with their hands, flattened it with a rolling pin (bhelna) and then baked it on the oiled tawa. This large paratha roti was then broken up using a large oar (dabla) which rendered smaller handfuls which could be quickly shared out to hungry diners squatting on the ship's floor. This diasporic version of the paratha is quite different from the South Asian variety, an invention created by necessity. In the Caribbean areas of settlement, the most popular street food, 'doubles', was created on the sugar estates. The 'doubles' consists of a sandwich in which two flatbreads (barras) are filled with curried chickpeas (channa) topped up by a desired flavouring (pepper, mango curry or a sweet or sour condiment).

The cultural landscape of the Caribbean was also changed by the introduction of a wide range of religious observances. In his Nobel Acceptance address the poet Derek Walcott celebrated two of these which he attended in Trinidad. One was the Muslim celebration of Mohurram (Hosay) complete with replicas of the tombs (tazias) of the grandsons of the Prophet $(u w b p)$ in the Port of Spain suburb of St James. The other much larger celebration was the dramatisation of the Ramleela story drawn from the Hindu epic the Ramayana. The Ramleela is the most popular Indian diasporic festival since its theme is that of banishment, exile and triumphant return, which was the aspiration of those who were indentured abroad. Performances are spread over weeks in the Hindu month of Ashwin (September-October) and are played on large fields in the sugar-cane villages: 
Here in Trinidad I had discovered that one of the greatest epics of the world was seasonably performed, not with desperate resignation of preserving a culture, but with an openness of belief that was as steady as the wind bending the cane lances of the Caroni plains... Visual surprise is natural in the Caribbean; it comes with the landscape, and faced with its beauty, the sigh of History dissolves. (Walcott 1992)

\section{CONCLUSION}

As the Caribbean moves further into the twenty-first century and as modern communications technology enables easier connectivity, the physical manifestations of India in the Caribbean have increased. India's rise as a world power after a long colonial past has also given a new sense of pride among its diasporic descendants. In Guyana a 50ft Hanuman statue has been erected at Leguan, rivalling the 85ft Hanuman murti at Waterloo in Trinidad. For Guyana, Karna Bahadursingh has published a properly documented description of the changes in Guyanese religious topography wrought by the Hindu and Muslim presence (Singh 1980). In Jamaica to which some 45,000 girmityas were transported from India, there remain tangible mementos of Indian influence. Wattle and daub houses, chulhas (firesides), jata (grindstones), places of worship and a wide range of musical instruments were reinvented there. Many of these were taken to Belize to which Indians went after completion of their Jamaican work (Mansingh and Mansingh 1999: chapters 6-10). The colonies of the diaspora were the creations of European capitalism as Europe enhanced its declining fortunes through the acquisition of overseas possessions using First Peoples and African labour initially and after Emancipation (1838) indentured Portuguese, Chinese and Indian labour. All of these peoples have together created small worlds in each settlement, incorporating the cultural and physical attributes of disparate ancestries. In that process the Caribbean landscape was physically enhanced through the introduction of flora and fauna from the Orient which changed 
consumption patterns, decreasing the dependence on imports from North America and Europe. Culturally, these new arrivals, coming from ancient civilisations, introduced a wide range of ancestral rituals which promoted social cohesion. There were now new rites of passage, seasonal festivals and musical instruments which complemented the preceding African recreations. These nineteenth-century immigrants did not look back in anger; they looked forward with hope ensuring their survival through thrift and hard labour. By the mid-twentieth century they had spawned their own diaspora to North America and Europe carrying with them a refreshing Caribbean creativity.

\section{NOTES}

1 Department of Agriculture Bulletin (Trinidad), 18 (1919).

2 British National Archives (BNA) CO 295/381. 22154 Memo by C. Warner, Emigration Agent, Calcutta.

3 BNA CO 295/446. 7711 Jerningham to Chamberlin, 27 September 1897.

4 CO295/381. C.O.Note. 19 October 1897.

5 Agri-News (Trinidad), 1(8) (August 1902).

6 CO295/446. File 47711. Kay to Colonial Secretary, 25 November 1908.

7 This section is based on the records of Caroni (1975) Ltd. Also Rastogi and Rastogi 2004.

8 Faculty of Agriculture, UWI., St. Augustine. 2017.

9 This paragraph is based on Gould 2004 and the author's own observations.

\section{REFERENCES}

Beall, J. 1990. 'Women under Indentureship in Natal' in S. Bhana (ed.), Essays on Indentured Indians in Natal (Leeds: Peepal Tree Press).

Bennett, S. P., G. W. Garcia and P. Lampkin. 2003. 'The Buffalypso: The Water Buffalo of Trinidad and Tobago', Italian Journal of Animal Science, 6(suppl. 2): 179-83.

Frawley, D. 2001. The Rig Veda and the History of India (New Delhi: Aditya Prakashan). 
Gould, Carol. 2004. The Remarkable Life of William Beebe (Washington, DC: Shearwater Books).

Lamming, G. 2001. 'Caribbean Labor, Culture and Identity' in G. Griffith (ed.), Caribbean Cultural Identities (Lewisburg, PA, and London: Bucknell University Press).

Mahabir, K. 2004. 'Animals from India to the Caribbean', Zoological Survey of India, 103(1-2): 179.

Mansingh, L. and A. 1999. Home Away from Home (Kingston, Jamaica: Ian Randle).

Patton, W. A. 1887. Down the Islands: A Voyage to the Caribbean (New York: Negro Universities Press).

Pemberton, R. 2000. 'Shaping the Caribbean Environment' in R. Chakrabarti (ed.), Situating Environmental History (New Delhi: Manohar).

Rastogi, L. and R. 1995. The Water Buffaloes of Trinidad and Tobago: Part of the East Indian Heritage (Trinidad: University of the West Indies).

Singh, K. N. 1980. Temples and Mosques: An Illustrated Study of East Indian Places of Worship in Guyana (Guyana: Release Publishers).

Vahed, G. 1995. 'The Making of Indian Identity in Durban, 1914-1949', Ph.D. thesis. University of Indiana.

Walcott, D. 1992. The Antilles: Fragments of Epic Memory (New York: Farrar, Straus \& Giroux).

Warner, C. 1897. British National Archives (BNA) CO295/381. 22154 Memo by C. Warner, Emigration Agent, Calcutta. 